\title{
Ocena płynności mówienia
}

\section{The assessment of speech fluency}

\author{
Tomasz Woźniak ${ }^{1}$, Joanna Soboń ${ }^{2}$ \\ ${ }^{1}$ Uniwersytet Marii Curie-Skłodowskiej, Zakład Logopedii i Językoznawstwa Stosowanego, Lublin \\ ${ }^{2}$ Zespół Szkół nr 2 w Świdniku, Świdnik
}

Adres autora: Tomasz Woźniak, Uniwersytet Marii Curie-Skłodowskiej, Zakład Logopedii i Językoznawstwa Stosowanego, ul. Sowińskiego 17, 20-040 Lublin, e-mail: twozniak@vp.pl

\begin{abstract}
Streszczenie
W artykule dokonano krytycznego przeglądu metod oceniających płynność mówienia. Przegląd uwzględnia zarówno metody stosowane w Polsce, jak i na świecie. Oceny metod dokonano w odniesieniu do przyjętych na wstępie definicji płynności i niepłynności mówienia. $\mathrm{W}$ artykule przedstawione zostały również dane pozwalające na ustalenia normatywne, umożliwiające ocenę płynności wypowiedzi. W konkluzji autorzy rekomendują modelowe rozwiązanie przeznaczone do rzetelnej klinicznej oceny płynności mówienia.
\end{abstract}

Słowa kluczowe: metody oceny płynności mówienia • definicje płynności i niepłynności mówienia • kliniczna ocena płynności mówienia

\begin{abstract}
The article is the critical review of methods to assess speech fluency. The revision concerns both the methods used in Poland and in the world. Evaluation methods shall be made in relation to the definitions of fluency and disfluency of speaking adopted at the outset. The article presents data to determine norms allowing the evaluation of fluency. In conclusion, the authors recommend a model solution for reliable clinical assessment of fluency.
\end{abstract}

Key words: methods to assess speech fluency • definitions of fluency and disfluency of speaking • clinical assessment of speech fluency

\section{Wstęp}

Podstawowym zamierzeniem autorów niniejszego artykułu jest opis i analiza metod oceny płynności mówienia w celu wyboru rozwiązań, które pozwalają na obiektywną i skuteczną klinicznie (diagnostycznie i terapeutycznie) ocenę tego zjawiska. Wzięto także pod uwagę możliwości oceny płynności za pomocą technik komputerowych.

W artykule podejmującym problem oceny płynności mówienia sprawą pierwszorzędną jest zdefiniowanie pojęcia „płynność mówienia” oraz sporządzenie indeksu cech koniecznych do opisywania tego zjawiska. Dopiero na tej podstawie można rozważać zagadnienia związane $\mathrm{z}$ zaburzeniami płynności mówienia, w tym określenie kryteriów pozwalających na odróżnienie płynności mówienia od niepłynności: normalnej i patologicznej. Ze względu na tradycję kliniczną „niepłynność normalną” określać będziemy mianem „niepłynności fizjologicznej”. Przy czym w logopedii na zjawisko normalnej, czyli akceptowanej niepłynności mówienia - prócz procesów fizjologicznych - składają się również procesy związane $\mathrm{z}$ planowaniem semantyczno-syntaktycznym wypowiedzi, emocjami czy też rozpoznawaniem sytuacji mówienia. W naszym rozumieniu niepłynność patologiczna jest objawem występującym w różnych jednostkach zaburzeń mowy, dlatego też osobną kwestią pozostaje w dalszej perspektywie różnicowanie typów niepłynności patologicznej, obserwowanych w przypadkach poszczególnych zaburzeń: jąkania, giełkotu, dyzartrii, oligofazji itd.

Na tym tle dopiero należy rozważać różne metody oceny płynności wypowiedzi: kliniczne metody oceny niepłynności mówienia - próby sylabowe i wyrazowe, czy też testy fluencji słownej.

\section{Definicje płynności i niepłynności mówienia}

Wiele opracowań dotyczących patologii mowy miesza terminy 'jąkanie' (termin określający specyficzne zaburzenie mowy) i 'niepłynność' (objaw jąkania oraz innych zaburzeń), jak również nie przyjmuje określonej definicji 'płynności wypowiedzi', traktując ją jako oczywistą normę, podlegającą naturalnej obserwacji i ocenie. Stanowiska takie nie mogą być jednakże przyjęte w refleksji naukowej. 
Aby zdefiniować płynność mówienia, należałoby podjąć próby odpowiedzi na pytania podstawowe: Skąd wiemy, że ktoś mówi płynnie? Kiedy zauważamy niepłynność? Jaka niepłynność staje się patologiczna w ocenie słuchacza, a jaka w ocenie mówcy? Udzielenie wyczerpujących odpowiedzi na te pytania jest możliwe tylko dzięki badaniom eksperymentalnym. Próby takie są podejmowane na gruncie nowoczesnej fonetyki [1]. W prezentowanym artykule w małym zakresie uwzględniamy badania fonetyczne, a w większym stopniu odnosimy się do badań eksperymentalnych z zakresu logopedii $[2,3]$.

Płynnością mówienia nazwijmy bezproblemowe budowanie ciągu fonicznego zrozumiałego dla odbiorcy. Płynność polega na ciągłości realizacji następujących po sobie dźwięków mowy, które występują w obrębie regularnie powtarzających się grup rytmicznych (fraz), trwających około 2-3 sekund, niemalże identycznie uporządkowanych pod względem prozodycznym. Fraza może być wypełniona różną liczbą głosek (sylab), w zależności od tempa mówienia. Pomiędzy frazami występuje krótka pauza, której czas trwania nie jest ściśle określony. W wypadku nieprzerywanej wypowiedzi powinna być jednak krótsza niż 2 sekundy, nie ma bowiem wtedy wartości znaczącej [4-9]. Nierozstrzygnięte pozostaje zagadnienie normalnego tempa mówienia. Wierzchowska [10] przyjmuje na podstawie badań fonetycznych, że średnie tempo mówienia wynosi w rozmowie potocznej 10-12 głosek (4-5 sylab) na sekundę. Według badań z zakresu patologii mowy wartości te są inne i zależne od wieku, np. dzieci w 3 r.ż. prezentują tempo 116-163 sylaby na minutę (1,93-2,7 sylaby/s), dzieci w 6 r.ż. 140-175 sylab na minutę (2,30-2,9 sylaby/s), dorośli $162-230$ sylab na minutę $(2,7-3,8$ sylaby/s) [11].

\begin{abstract}
Niepłynnością mówienia określmy zaburzenie ciągłości wymawianiowej i rytmiczności następstwa fraz. Oznacza to przerwanie ciągłości realizacji fonicznej wypowiedzi w ramach następujących po sobie grup rytmicznych i zaburzenie regularnego następstwa czasowego tych grup (fraz). W zależności od rodzaju objawów i ich nasilenia możemy kwalifikować niepłynność mówienia jako fizjologiczną i patologiczną [4]. Jak wykazują badania, całkowita płynność mówienia jest zjawiskiem rzadko spotykanym. Powstają zatem pytania: Ile niepłynności jest dopuszczalne, aby nie zakłócać komunikacji? Jakiego rodzaju mogą to być niepłynności?
\end{abstract}

\section{Kryteria oceny płynności mówienia}

Na podstawie objawów niepłynność mówienia możemy analizować pod względem jakości i ilości występujących symptomów. Stanowisko to jest powszechnie przyjmowane w logopedii.

\section{Analiza jakościowa symptomów niepłynności}

Odnosząc się do jakości występujących objawów w wypowiedziach niepłynnych, należy przeanalizować zjawiska składające się na płynność mowy i określić, w jaki sposób zostały zaburzone. Literatura przedmiotu podsuwa przeważnie różne propozycje klasyfikacji zjawisk występujących w niepłynności. Odnoszą się one do:

1) miejsca występowania niepłynności: „jąkanie na starcie” i ,jąkanie w toku mówienia” [6],
2) nasilenia, ilości i rodzaju występujących przejawów niepłynności: niepłynność prosta (występowanie jednego objawu), niepłynność złożona (występowanie kilku objawów niepłynności); izolowane lub łączne występowanie powtarzania, przeciągania, blokowania, embolofazji, pauz, rewizji, tachylalii, bradylalii bądź dysrytmii;

3) występowania objawów neuromięśniowych towarzyszących niepłynności: niespastycznych i spastycznych (tonicznych, klonicznych i toniczno-klonicznych);

4) uwzględniania stopnia uświadomienia występowania niepłynności: niepłynność uświadomiona i nieuświadomiona;

5) określenia stanów i zachowań lękowych (logofobii) towarzyszących niepłynności: niepłynność logofobiczna i nielogofobiczna [12].

$\mathrm{Z}$ fonetycznego punktu widzenia na niepłynność mówienia składają się zjawiska związane z zaburzeniem następujących czynników prozodycznych: iloczasu, rytmu mówienia, koartykulacji, tempa i melodii mówienia [4].

Iloczas to długość trwania głoski. Każdy dźwięk artykułowany ma określony czas trwania, choć jest to wartość w dużym stopniu zmienna i może wpływać na formę wypowiedzi. Nie można jednak naruszać reguł realizacji systemu fonologicznego języka, w którym istnieją określone limity czasowe realizacji.

Rytm mówienia można zdefiniować jako okresowe powtarzanie się podobnie długo trwających i identycznie uporządkowanych procesów, połączonych w jedną całość szczytem dynamicznym. Następujące po sobie frazy nie muszą być jednakowe, ale przeważa tendencja do regularnego, uporządkowanego w czasie następstwa przycisku i braku przycisku. Wynika $\mathrm{z}$ tego, że musimy postrzegać zaburzenia rytmu mówienia jako rzecz szczególnie nieprzyjemną, dlatego w codziennej komunikacji staramy się „zamaskować" je za pomocą głosek czy wyrazów wypełniających ciszę. Zaburzenia rytmiczne są jednymi z podstawowych objawów niepłynności. Wśród nich można wymienić: pauzy, wprowadzanie wyrazów i dźwięków dodatkowych, rozciągnięcie frazy w czasie.

- pauzy, które możemy analizować z punktu widzenia objawów głównie pod kątem czasu ich trwania, miejsca wystąpienia $\mathrm{w}$ ciągu fonicznym oraz innych symptomów towarzyszących ich występowaniu. $\mathrm{Z}$ tych względów za zwracające uwagę należy uznać wszystkie pauzy trwające powyżej 2 sekund. Bierzemy ponadto pod uwagę lokalizację pauz: czy są to przerwy między frazami, wyrazami czy w trakcie wyrazu. Pauzy występujące między frazami i wyrazami mogą być różnie kwalifikowane - jako normalne lub patologiczne. Pauzy związane z zatrzymaniem realizacji dźwięku w wyrazie, niezależnie od pozycji dźwiękowej, którą głoska zajmuje, zawsze powinny być uznane za patologiczne. Jeżeli towarzyszy temu obserwowalny wzrost napięcia mięśniowego (spastyczność), kwalifikacja patologicznego charakteru niepłynności nie budzi wątpliwości. Tego rodzaju objawy najczęściej dotyczą dźwięków w pozycji nagłosowej i nazywamy je „blokami”,

- wprowadzenie wyrazów i dźwięków dodatkowych stanowi jeden z podstawowych sposobów maskowania zaburzeń rytmicznych. Należy jednak odróżnić „konwencjonalne" pauzy wypełnione od pauz będących wynikiem lęku antycypacyjnego w jąkaniu, 
- rozciągnięcie frazy w czasie, ponad jej przewidzianą wartość rytmiczną, może wynikać $\mathrm{z}$ różnych zjawisk - głównie przeciągania, blokowania lub powtarzania dźwięków. Realizacja frazy (jednostki rytmicznej, ale też jednostki sensu) przeciągnięta ponad 3 sekundy zaburza percepcję wypowiedzi. U osób jąkających się średni czas trwania realizacji frazy wynosi 7 sekund [9]

Koartykulacja to umiejętność przechodzenia jednej sekwencji ruchów artykulacyjnych w drugą i ich wzajemne nakładanie się. Koartykulacja rozpatrywana przy okazji niepłynności mówienia dotyczy nie tyle nieprawidłowości w realizacji upodobnień, ile wymowy połączeń samogłosek ze spółgłoskami (głównie zwarto-wybuchowymi) i grup spółgłoskowych oraz powtarzania. Trudności koartykulacyjne w przechodzeniu od dźwięku do dźwięku tylko częściowo przejawiają się w przeciągnięciach czy pauzach. Objawem niepłynności wymagającym osobnego komentarza jest tu powtarzanie. Powtarzanie można rozpatrywać pod następującymi względami:

- długości powtarzanego segmentu (fraza, wyraz, sylaba, głoska),

- liczby powtórzeń,

- miejsca występowania powtórzeń (w przypadku powtarzania głosek i sylab): nagłos, śródgłos, wygłos.

Tempo mówienia jest definiowane jako liczba głosek wypowiadanych w jednostce czasu. Głoski artykułowane $\mathrm{w}$ danej wypowiedzi podlicza się, po czym dzieli się tę sumę przez liczbę sekund, abstrahując od pauz [5]. Jak wspomniano wcześniej, jest to wartość dyskusyjna i w dużym zakresie zmienna w komunikacji ludzkiej. Tempo mówienia waha się od około 5 głosek (2 sylab) na sekundę przy wolnym sposobie mówienia do 10-12 głosek (4-5 sylab) przy ożywionej rozmowie. Tempo powyżej tej wartości można uznać za przyspieszone, a wartość 21 głosek na sekundę za bliską maksymalnej szybkości mowy ludzkiej, zależnej od procesów programowania i artykulacji dźwięków, a także zdolności rozdzielczej narządu słuchu i możliwości percepcyjnych człowieka [10].

Melodia mowy zawiera w sobie szereg informacji istotnych dla wyrażania ekspresji, dekodowania intencji mówiącego, ale też istotnych z punktu widzenia informacji syntaktycznej o podziale i typach wypowiedzeń. Na melodyczną organizację wypowiedzi składają się czynniki takie jak: wysokość tonu podstawowego, przebiegi intonacyjne (kadencja, antykadencja, intonacja otwarta), zestroje intonacyjne. Czynniki te mają zasadnicze znaczenie dla organizacji rytmicznej wypowiedzi. Ich zaburzenie świadczy o patologicznej realizacji wypowiedzi i zwykle wiąże się $\mathrm{z}$ występowaniem przeciągnięć, bloków i powtórzeń, którym towarzyszy napięcie mięśniowe obejmujące także mięśnie krtani.

Lista wymienionych wyżej fonetycznych objawów niepłynności powinna być uzupełniona o indeks symptomów towarzyszących niepłynności patologicznej. Ich obecność pozwala na pewniejszą kwalifikację obserwowanych przejawów niepłynności jako patologii. Należy w tym kontekście wymienić:

1. Zaburzenia napięcia mięśniowego w obrębie narządów mowy, które wiążą się głównie $\mathrm{z}$ podwyższeniem napięcia (spastycznością), choć mogą też przybrać postać obniżenia napięcia mięśniowego narządów artykulacyjnych, np. w dyzartrii czy zespole Downa. Podwyższenie napięcia mięśniowego zwykle powoduje pojawienie się ruchów (współruchów) zbędnych z punktu widzenia komunikacji, obejmujących mięśnie twarzy, szyi, tułowia, a nawet kończyn. Ruchy te mają subiektywnie „pomóc" w pokonaniu napięcia i niepłynności (w jąkaniu są $\mathrm{w}$ dużej mierze reakcją wyuczoną). Wyjątek może stanowić zespół Tourette’a, w którym współruchy i tiki są względnie niezależne od czynności mówienia, powodowane są bowiem przez zaburzenia neurologiczne.

2.Zaburzenia oddechowe, które można podzielić na zaburzenia toru oddechowego (głównie oddech szczytowy) oraz koordynacji oddechu, fonacji i artykulacji (niepłynność na bezdechu, wdechu, podparciu). Oba przypadki uznajemy za ważne w ocenie patologiczności niepłynności.

3. Zaburzenia kontaktu wzrokowego towarzyszące niepłynności wskazują, że pacjent doświadczał już niepłynności wielokrotnie i wstydzi się jej. Zamykanie oczu, uciekanie od kontaktu „twarzą w twarz” jest argumentem za patologicznym charakterem niepłynności.

4. Zaburzenia artykulacyjne o charakterze segmentalnym, które towarzyszą niepłynności patologicznej w giełkocie i dyzartrii.

5. Spójność wypowiedzi, która jest przeważnie zachowana w wypowiedziach osób jąkających się, a może być naruszona w przypadkach giełkotu. Należy zwrócić uwagę na konieczność uwzględnienia tej kategorii w ocenie nawet w normie - wypowiedzi niepłynne mogą być mniej spójne, co świadczy zwykle o większej emocjonalności wypowiedzi i wzajemnym powiązaniu emocji, procesów tworzenia tekstu oraz płynnego ciągu fonicznego.

\section{Ilościowa ocena niepłynności}

Zwykle dokonujemy oceny ilościowej na podstawie tak zwanej „próby wyrazowej” lub „próby sylabowej”. W pierwszym przypadku bierze się pod uwagę liczbę niepłynnie wypowiedzianych wyrazów w stosunku do ogólnej liczby wypowiedzianych wyrazów, a uzyskany wynik mnoży przez sto procent. Analogicznie postępuje się w przypadku „próby sylabowej”, tylko obliczany procent dotyczy liczby niepłynnie zrealizowanych sylab w stosunku do ogólnej liczby wypowiedzianych sylab.

Ciekawą propozycją w ostatnich latach jest postulat oceny realizacji płynności w interwałach czasowych - na przykład wypowiedź 1-minutową można podzielić na 15 odcinków po 4 sekundy i sprawdzić, ile $\mathrm{z}$ nich jest realizowane płynnie. Brak jest jednak konkretnych zastosowań praktycznych tej propozycji [2].

Interesujące wyniki przynosi zestawienie danych zawartych w pracy Einarsdóttir i Inghama [3]. Przedstawili oni dane dotyczące niepłynności występujących u dzieci w okresie rozwoju mowy, porównując dzieci jąkające się z ich płynnie mówiącymi rówieśnikami (tabela 1).

Jak wynika z powyższego zestawienia, średnia norma dla próby wyrazowej wynosi $5,79 \%$, zaś dla próby sylabowej 5,25\%. W świetle powyższych ustaleń różnica między oceną za pomocą próby sylabowej lub wyrazowej staje się mało istotna. Zwraca na to także uwagę Yaruss [2], 
Tabela 1. Porównanie występowania niepłynności mówienia w wypowiedziach dzieci jąkających się i mówiących płynnie w okresie rozwoju mowy (oprac. własne na podstawie: Einarsdóttir, Ingham 2005, s. 263)

Table 1. Comparing of the incidence of the nonfluency of speaking in stuttering children and in children speaking fluently in the period of speech development (own study based on: Einarsdóttir, Ingham 2005, s. 263)

\begin{tabular}{lcc}
\hline Badania przy użyciu próby wyrazowej & $\begin{array}{c}\text { Dzieci jąkające się } \\
\text { - procent realizacji nieptynnych }\end{array}$ & $\begin{array}{c}\text { Dzieci mówiące płynnie } \\
\text { - procent realizacji nieptynnych }\end{array}$ \\
\hline Johnson i wsp. (1959) & $\begin{array}{c}\text { Chłopcy 17,91 } \\
\text { Dziewczynki 16,25 }\end{array}$ & $\begin{array}{c}\text { Chłopcy 7,28 } \\
\text { Dziewczynki 7,90 }\end{array}$ \\
\hline Pellowski i Conture (2002) & 10,70 & 2,60 \\
\hline Zacheim i Conture (2004) & 12,70 & 5,40 \\
\hline Badania przy użyciu próby sylabowej & & 6,18 \\
\hline Yairi i Lewis (1984) & 21,46 & 5,89 \\
\hline Hubard i Yairi (1988) & 22,45 & 5,65 \\
\hline Ambrose i Yairi (1999) & 15,78 & 3,30 \\
\hline Logan (2003) & 9,64 & \\
\hline
\end{tabular}

zauważając przy tym, że w przypadku dzieci przeważają słowa jednosylabowe, a u dorosłych, w potocznej wypowiedzi, średnia długość używanych form wyrazowych wynosi 1,5 sylaby. Należy zaznaczyć, że dane te odnoszą się do języka angielskiego.

Cooper za wartość graniczną uznał 5\% niepłynnie realizowanych wyrazów, w większości sytuacji wymagających mówienia, obserwowanych przez co najmniej pół roku, zarówno u dzieci, jak i u dorosłych [13].

Propozycje rozwiązania tej kwestii przynoszą także badania Kurkowskiego [14]. Analizowano wypowiedzi 200 osób w wieku od 6 do 28 lat metodą sędziów kompetentnych. Wyniki tych analiz pozwalają uznać za płynną tę wypowiedź, w której nasilenie objawów nie przekracza 3\% u dzieci i $2 \%$ u dorosłych w próbie sylabowej.

Uwzględniając te dane, można przyjąć, że granicą patologii jest 5\% całkowitej niepłynności ocenianej w próbie sylabowej. Zatem wynik większy/równy 5\% uznać należy za patologiczne nasilenie niepłynności. Na uznanie tego wyniku za wartość graniczną wpływa zarówno uwzględnienie przypadków rozwojowej niepłynności mówienia, założenie pewnego zakresu tolerancji dla określenia granic normy (podobnie jak „odchylenie standardowe”), jak i doświadczenia płynące z praktyki klinicznej. W praktyce logopedycznej należy brać pod uwagę kryterium jakości i liczby objawów jako równie ważne. Nawet mniejsza niż 5\% liczba ewidentnie patologicznych symptomów niepłynności może zadecydować o konieczności pomocy terapeutycznej. Za minimalną wartość graniczną należałoby zatem uznać 3\% przy objawach spastycznych przeciągnięć, wielokrotnych powtórzeń sylab lub głosek, pauz międzywyrazowych trwających powyżej 2 sekund.

$\mathrm{W}$ podsumowaniu proponujemy zestawienie pozwalające na odróżnienie niepłynności fizjologicznej i patologicznej (tabela 2).

\section{Niepłynność mówienia w patologii mowy}

W logopedii niepłynność mówienia jest objawem, który występuje w różnych jednostkach patologii mowy: jąkaniu, giełkocie, dyzartrii, afazji, w wypowiedziach ludzi z chorobą Parkinsona, nerwicami mowy, autyzmem, oligofazją, syndromem Tourette’a czy zaburzeniami słuchu. Etiologia niepłynności w wymienionych przypadkach jest ściśle związana z patologią procesów leżących u podstaw czynności mowy $[15,16]$. Osobną kwestię stanowi „rozwojowa niepłynność mówienia”, która jest zjawiskiem normalnym w okresie rozwoju mowy i u niektórych dzieci występuje w większym nasileniu [13].

Należy podkreślić, że utożsamianie terminu 'niepłynność mówienia' $\mathrm{z}$ terminem 'jąkanie' $\mathrm{w}$ ujęciu potocznym jest błędem i może prowadzić do nieporozumień w ocenie płynności wypowiedzi. Synonimiczne traktowanie obu pojęć stwarza realne ryzyko obliczania „odsetka jąkania” zamiast „odsetka niepłynności mówienia” w zaburzeniach mowy.

W przypadku jąkania - pojętego jako zespół - specyficznie patologiczna niepłynność mówienia (odsetek większy niż $5 \%$ w próbie sylabowej, przerwy dłuższe niż 2 sekundy) jest symptomem podstawowym. Polega przede wszystkim na blokowaniu, przeciąganiu, powtarzaniu dźwięków mowy (objawy prymarne) oraz stosowaniu dźwięków wtrąconych, pauz wypełnionych, wielokrotnych powtórzeń wyrazów lub fraz (objawy sekundarne). Wykazuje dużą zależność od zmiennych interakcyjnych: osoby rozmówcy, sytuacji, celu i gatunku wypowiedzi. Niepłynności towarzyszą reakcje lękowe o charakterze patologicznym, związane ze świadomością zaburzenia i przewidywaniem wystąpienia niepłynności (logofobia) oraz podniesione napięcie mięśniowe w obrębie narządów mowy (spastyczność) [17].

W praktyce klinicznej kwestią kluczową jest dostrzeżenie odrębności jąkania względem innych jednostek patologii mowy, w symptomatologii których pojawia się niepłynność. W diagnozie różnicowej jąkania i pozostałych zaburzeń płynności mówienia należy zatem wziąć pod uwagę również dodatkowe symptomy towarzyszące niepłynności. 
Tabela 2. Objawowe kryteria rozróżnienia niepłynności fizjologicznej i patologicznej [por. Woźniak 2013, s. 563] Table 2. Symptomatic criteria to discriminate normal and pathological nonfluency [por. Woźniak 2013, s. 563]

\begin{tabular}{|c|c|c|}
\hline \multirow{2}{*}{ Objawy } & \multicolumn{2}{|c|}{ Opis objawów z uwzględnieniem reakcji i zachowań im towarzyszących } \\
\hline & Niepłynność fizjologiczna & Niepłynność patologiczna \\
\hline $\begin{array}{l}\text { Całkowita liczba niepłynności } \\
\text { w próbie sylabowej }\end{array}$ & Mniej niż 5\% & $\begin{array}{l}\text { Ogólnie 5\% lub więcej; } \\
\text { 3\% i więcej przy wyraźnych objawach } \\
\text { jakościowych }\end{array}$ \\
\hline Przeciągnięcia & Niespastyczne & Spastyczne i niespastyczne \\
\hline Pauzy & $\begin{array}{l}\text { Przeważnie między dwoma frazami lub } \\
\text { wyrazami, do } 2 \text { sekund, bez napięcia } \\
\text { mięśniowego }\end{array}$ & $\begin{array}{l}\text { Przeważnie związane z zatrzymaniem realizacji } \\
\text { dźwięku, dłuższe niż } 2 \text { sekundy, z widocznym } \\
\text { napięciem mięśniowym }\end{array}$ \\
\hline Wyrazy i dźwięki wtrącone & $\begin{array}{l}\text { Typowe w danym języku „pauzy } \\
\text { wypełnione” }\end{array}$ & $\begin{array}{l}\text { Typowe i nietypowe,„pauzy wypełnione”, nic } \\
\text { nieznaczące wokalizacje }\end{array}$ \\
\hline Czas trwania frazy & $2-3$ sekundy & $\begin{array}{l}\text { Poniżej } 2 \text { sekund (wypowiedź rozbita na } \\
\text { pojedyncze wyrazy, skandowana) lub powyżej } \\
3 \text { sekund }\end{array}$ \\
\hline Powtórzenia & $\begin{array}{l}\text { Przeważnie fraz i wyrazów, rzadziej } \\
\text { sylab i głosek, tylko na początku wyrazu, } \\
\text { jednokrotne }\end{array}$ & $\begin{array}{l}\text { Przeważnie sylab i głosek, we wszystkich } \\
\text { pozycjach dźwiękowych, ale też wyrazów i fraz, } \\
\text { więcej niż raz }\end{array}$ \\
\hline Tempo mówienia & Normalne & $\begin{array}{l}\text { Zmienne w momentach niepłynności (zwolnienia, } \\
\text { przyspieszenia), stale przyspieszone lub stale } \\
\text { zwolnione }\end{array}$ \\
\hline Melodia wypowiedzi & Prawidłowa & $\begin{array}{l}\text { Zaburzenia wysokości głosu, nieprawidłowa } \\
\text { intonacja, częste dodatkowe zaburzenia siły } \\
\text { głosu (głos zbyt cichy lub podniesiony) }\end{array}$ \\
\hline Zaburzenia oddechowe & Nie występują & $\begin{array}{l}\text { Mogą występować, często z towarzyszącym } \\
\text { napięciem mięśniowym i współruchami }\end{array}$ \\
\hline Poprawność wymawianiowa głosek & Prawidłowa & $\begin{array}{l}\text { W wielu przypadkach obniżona (giełkot, } \\
\text { dyzartria) }\end{array}$ \\
\hline $\begin{array}{l}\text { Zaburzenia kontaktu wzrokowego } \\
\text { w momentach niepłynności }\end{array}$ & Nie występują & Często występują przy niepłynności w jąkaniu \\
\hline
\end{tabular}

Największe podobieństwo do jąkania zdradza giełkot. Objawy niepłynności w większości różnią się od objawów jąkania i polegają głównie na niespastycznych powtórzeniach, stosowaniu pauz, dźwięków wtrąconych. Można uznać, że specyficzna niepłynność mówienia w giełkocie pojawia się na skutek słabszej integracji procesów programowania wypowiedzi oraz deficytów jej kontroli. Stąd prawdopodobnie obecność naruszonej spójności wypowiedzi, szybkiego i nieregularnego tempa mówienia, licznych powtórzeń i błędów, gorszego funkcjonowania uwagi słuchowej czy braku świadomości występujących trudności [18], a tym samym - na ogół niewielkiego zainteresowania problemem niepłynności mówienia wyrażanego przez pacjenta $\mathrm{z}$ giełkotem.

Niepłynność mówienia w dyzartrii - obok dysfunkcji oddechowych, fonacyjnych, artykulacyjnych i rezonansowych - jest objawem niejako drugoplanowym. Objawia się zwykle częstymi pauzami, powtarzaniem dźwięków, zaburzeniami tempa mówienia oraz nieprawidłowym akcentem. Kryterium objawowe w zakresie niepłynności mówienia najwięcej jej oznak nakazuje doszukiwać się kolejno w dyzartrii: móżdżkowej, pozapiramidowej hiperkinetycznej, pozapiramidowej hipokinetycznej czy też piramidowej [Kurkowski 2003]. Niepłynność mówienia w zaburzeniach dyzartrycznych ma charakter organiczny, a co się z tym wiąże - bardziej stały przebieg. Towarzyszą jej zaburzenia artykulacyjne o charakterze segmentalnym [19].
Za teoretyczną podstawę do opisu niepłynności mówienia u pacjentów afatycznych należy uznać teorię układów funkcjonalnych Aleksandra Łurii [20]. Zgodnie z przyjętą taksonomią afazji zaburzenia płynności mówienia należy upatrywać przede wszystkim w afazji motoryczno-odśrodkowej (kinetycznej). W praktyce klinicznej obserwujemy: powtarzanie głosek bądź sylab na skutek perseweracji, nieprawidłowości w melodii mowy i akcentowaniu, skandowanie. Zaburzenia sygnalizacji odśrodkowej odpowiedzialne są za częściową lub całkowitą utratę płynności mówienia u chorego. Pewne elementy niepłynności możemy dostrzec także w afazji semantycznej, w której występują: powtórzenia, pauzy czy embolofazje [21]. Niepłynności mówienia w zaburzeniach afatycznych nie towarzyszy ani logofobia, ani też spastyczność w obrębie narządów artykulacyjnych.

W przypadku niepłynności mówienia występującej w przebiegu choroby Parkinsona rolę kluczową pełnią: dane uzyskane w trakcie wywiadu (informacja o późnym początku zaburzeń płynności mówienia), z dokumentacji medycznej diagnozowanej osoby (badania neurologiczne) [22] oraz jakościowa ocena symptomów niepłynności (brak spastyczności, niewyraźna artykulacja).

Z kolei nerwice mowy (logoneurozy) w piśmiennictwie ujmowane są w odniesieniu do zaburzeń psychicznych o zróżnicowanej symptomatologii. Badacze zaburzeń nerwicowych u dzieci i młodzieży wyliczają zwykle: zespół nadmiernego 
lęku, reaktywne zaburzenia przywiązania w dzieciństwie, fobie szkolne, nerwice natręctw czy też zaburzenia histeryczne [23]. Należy pamiętać, że dla nerwic mowy charakterystyczne jest przede wszystkim ograniczenie występowania objawów niepłynności mówienia wyłącznie do pewnych sytuacji, ściśle związanych z określoną jednostką nerwicową. Znamienna jest tu także mniejsza liczba objawów niepłynności oraz towarzyszące jej zaburzenia głosu. W skrajnych przypadkach może dojść nawet do zaniku głosu dźwięcznego przy nieobecności patologii organicznej krtani (afonia czynnościowa, psychogenna, histeryczna) [24].

Podstawą rozróżnienia jąkania i niepłynności mówienia w przypadku zaburzeń związanych z niewykształconymi sprawnościami percepcyjnymi (wypowiedzi osób z oligofazją czy autyzmem) jest zarówno brak spastyczności, jak i brak logofobii. Ponadto osoby z upośledzeniem umysłowym zwykle przejawiają trudności artykulacyjne. Jednocześnie warto zaznaczyć, że jąkanie, rozumiane jako zespół, występuje u osób upośledzonych umysłowo znacznie rzadziej niż u osób w normie intelektualnej [25].

Natomiast niepłynność mówienia w syndromie Tourette’a przybiera postać tików, tj. mimowolnych powtórzeń własnych słów, fraz lub sylab. Tiki i współruchy (ruchy zbędne pod względem komunikacji) są tu względnie niezależne od czynności mówienia i występują w wyniku zaburzeń neurologicznych. Istotną rolę w rozpoznaniu pełnią więc dane kliniczne uzyskane w trakcie konsultacji neurologicznej [26].

W przypadku osób z zaburzeniami słuchu niepłynność mówienia zwykle pojawia się przy niedosłuchach jednostronnych. Tutaj również nieodzowna wydaje się analiza dokumentacji medycznej pacjenta, w tym przede wszystkim - audiologicznej [27].

\section{Przegląd metod oceny płynności mówienia}

Pomiaru i oceny niepłynności zwykle dokonuje się w ramach badania o charakterze eksperymentalno-klinicznym, uwzględniającym: ocenę ilościową - częstotliwość niepłynności (próba sylabowa lub wyrazowa) i jakościową (ocena rodzaju niepłynności i objawów towarzyszących: obecność napięcia mięśniowego, występowanie zachowań niewerbalnych, subiektywna ocena trudności ze strony pacjenta itd.). Ocenę różnicuje się w zależności od: 1) typu zadania/zachowania werbalnego (czytanie, opis, opowiadanie, monolog, dialog neutralny/emocjonalny, powtarzanie),

2) sytuacji (np. gabinet logopedyczny, dom, szkoła, miejsce pracy, plac zabaw, sklep),

3) odbiorcy (np. terapeuta, rodzice, rodzeństwo, krewni, koledzy i koleżanki, współpracownicy, osoby nieznajome) [2,17].

W celu standaryzacji badania wykorzystuje się w czasie diagnozy różne testy, kwestionariusze i próby.

Biorąc pod uwagę technikę przeprowadzania pomiaru, można wskazać dwie strategie: pierwsza, kiedy ocena dokonywana jest na bieżąco („on-line”), i druga, gdy obliczenie wyników odbywa się po badaniu, na podstawie nagrania wypowiedzi pacjenta („off-line”). W pierwszym przypadku odnotowuje się linearnie wszystkie pojawiające się w trakcie wypowiedzi niepłynności (np. stawiając odpowiedni znak w tabeli z podaną liczbą sylab lub wykorzystuje się odpowiednie techniki komputerowe), w drugim protokół badania wypełniany jest przy odsłuchiwaniu nagrań po sesji diagnostycznej. W praktyce można używać obu sposobów, przy czym odrębną sprawą jest kwestia obiektywizacji pomiaru: dwóch logopedów może ocenić tę samą wypowiedź na różne sposoby [2].

Jak dowiedziono w eksperymencie klinicznym przeprowadzonym na Uniwersytecie w Londynie, podczas oceny częstotliwości niepłynności i czasu jej trwania można zastosować dwie odmienne procedury: procedurę pomiaru jednoczesnego (w trakcie badania jednocześnie liczona jest ogólna liczba sylab, liczba sylab niepłynnych i czas trwania niepłynności) oraz procedurę pomiaru kolejnego (w trakcie badania kolejno liczona jest ogólna liczba sylab, liczba sylab niepłynnych i czas trwania niepłynności). Oczywiście pomiar zakłada wykorzystanie technik skomputeryzowanych bądź stosownego oprzyrządowania, zaś liczenie odbywa się za pomocą przyciskania odpowiednich klawiszy [28].

Wydaje się, że najlepszym rozwiązaniem byłoby wprowadzenie technik obiektywizujących od strony formalnej (możliwość automatycznej detekcji przeciągnięć, powtórzeń, obliczenia czasu pauz) w połączeniu z odpowiednim kwestionariuszem obserwacji klinicznej.

Obiektywna ocena niepłynności mówienia jest możliwa dzięki zastosowaniu metod akustycznych w postaci specjalistycznych programów do automatycznego rozpoznawania niepłynności w mowie ciągłej. Interesującą propozycją wydaje się „Wave Blaster” - wszechstronne narzędzie do analizy mowy przy użyciu ciągłej transformaty falkowej ze skalami barkowymi [29]. Program ten bazuje na specjalnie opracowanych algorytmach detekcji trzech rodzajów niepłynności: przedłużeń dźwięków, powtórzeń dźwięków oraz powtórzeń sylab i umożliwia wieloparametrowy ogląd danych w postaci: oscylogramów, spektrogramów, widm czy obrysów sieci Kohonena [30-32]. Należy jednak zaznaczyć, że wspomniane narzędzie diagnostyczne jest wciąż w fazie optymalizacji do zastosowania w praktyce klinicznej.

Poszukując przykładów rozwiązań praktycznych służących do oceny niepłynności, dokonano poniżej przeglądu istniejących testów, kwestionariuszy i prób przydatnych do oceny płynności mówienia.

Pierwszym narzędziem, które czasem mylnie stosuje się do oceny płynności mówienia, jest Test Fluencji Słownej (ang. Verbal Fluency Test, VFT) ${ }^{1}$. Z psychometrycznego punktu widzenia VFT pozwala na wykrycie zaburzeń dotyczących sfery poznawczej, w tym na ocenę wielu funkcji, m.in. płynności słownej, procesów uwagi, szybkości przetwarzania informacji, pamięci operacyjnej i funkcji

\footnotetext{
1. W ramach Europejskiego Kongresu CPLOL we Florencji, 8-9 maja 2015 r., zaprezentowano wystąpienie Verbal fluency in adults with depresion (R. N. Soare i wsp.) w sesji poświęconej zaburzeniom płynności mowy.
} 
wykonawczych. Najbardziej rozpowszechnione są dwie wersje VFT: posługująca się kryterium formalnym (literowym, ang. phonemic fluency) i kryterium semantycznym (kategorialnym, ang. semantic fluency). Test płynności semantycznej polega na podaniu przez badanego jak największej liczby słów należących do pewnej kategorii (np. „owoce”, „warzywa”, „zawody”, „ostre przedmioty”, „kolory”, „produkty spożywcze”, ,imiona”, „części garderoby”). W fonetycznej wersji VFT badany generuje jak najwięcej słów zaczynających się na daną literę. Wybór liter wiąże się z niską lub wysoką frekwencją takich wyrazów w danym języku. Czas na wykonanie każdego zadania wynosi zwykle minutę [33].

Niepłynności mówienia nie ocenia również Kwestionariusz Niepłynności Mówienia i Logofobii (diagnoza i terapia jąkania) Z. Tarkowskiego [34]. Zawiera on w części A jedynie subiektywną ocenę (pacjenta lub rodzica) liczby sytuacji, w których występuje niepłynność, oraz podobną ocenę nasilenia niepłynności.

Test ten nie ocenia płynności mówienia wedle przyjętej definicji, zaś ocena zebranego przy jego użyciu materiału pod kątem płynności wypowiedzi może mieć jedynie wartość eksperymentalno-kliniczną, tak jak ocena innych wypowiedzi pacjenta.

Kwestionariuszem, który ocenia płynność mówienia, jest bez wątpienia kwestionariusz opracowany przez E. B. Coopera i C. Cooper, znany w Polsce jako Kwestionariusz Cooperów Oceny Jąkania (KCOJ) dzięki adaptacji M. Chęćka [35]. Wykorzystuje się w nim próbę wyrazową (jako pierwsze zadanie kwestionariusza), technika badania polega na zastosowaniu procedury oceny „off-line”. Ocenia się procent występowania niepłynności w próbach: wypowiadanie ciągów zautomatyzowanych, powtarzanie zdań, czytanie, odpowiadanie na pytania, wypowiedź swobodna. Wyniki sumuje się, a następnie dzieli przez liczbę zadań, otrzymując uśredniony wynik. W próbie tej ocenia się także tempo wypowiedzi. W KCOJ - jeśli chodzi o ocenę niepłynności - bierze się ponadto pod uwagę przeciętny czas trwania momentów niepłynności (próba druga) jak również objawy towarzyszące (nienaturalne reakcje - próba czwarta). KCOJ jest narzędziem nastawionym głównie na diagnozowanie jąkania jako zespołu objawów - inne próby dotyczą oceny logofobii, znaczenia zaburzenia w życiu pacjenta oraz percepcji jąkania przez pacjenta i terapeutę.

Próba sylabowa do oceny niepłynności mówienia Z. M. Kurkowskiego [14] służy do pomiaru niepłynności mówienia jako wyizolowanego objawu, niezależnie od zaburzenia. Została zróżnicowana wiekowo na cztery grupy: dzieci do 7 r.ż., dzieci w młodszym wieku szkolnym (8-12 r.ż.), młodzież (13-18 r.ż.) i dorośli. Dla każdej grupy przewidziano trzy próby: A. Czytanie, B. Odpowiedzi na pytania, C. Opowiadanie historyjki obrazkowej. Materiał do badań (obrazki, teksty, pytania, historyjki) dobrany jest do danej grupy wiekowej. Technika badania opiera się na procedurze „off-line”, zaś przy odsłuchiwaniu nagrań posługujemy się specjalnymi znakami na zapis płynnych i niepłynnych sylab oraz wtrąceń, w specjalnie opracowanych protokołach (tabelkach). Wyniki z trzech prób sumuje się i uśrednia. Do Próby... dołączono propozycje oceny stopnia niepłynności: w granicach normy $3 \%$, stopień lekki 4-12\%, umiarkowany
13-30\%, znaczny $31-55 \%$ oraz głęboki 56-100\%. Autor sugeruje także pomiar tempa mówienia.

W międzynarodowej literaturze logopedycznej funkcjonują różnorakie metody oceny płynności wypowiedzi (listy, diagramy, skale). Zasadnicze znaczenie ma przede wszystkim kwestia przydatności wybranych narzędzi w praktyce klinicznej, a jednocześnie ich rzetelności i obiektywizmu $\mathrm{w}$ procesie diagnostyczno-terapeutycznym osób z zaburzeniami płynności mówienia.

Opracowana w 1963 roku na Uniwersytecie Iowa Kontrolna lista reakcji $w$ jąkaniu (ang. Check list of stuttering reactions) [36] służy do przeprowadzenia skategoryzowanej obserwacji symptomów niepłynności mówienia (podczas wypowiedzi ustnej lub czytania) i towarzyszących im dodatkowych objawów o charakterze patologicznym (współruchy, artykulacja, oddychanie, fonacja). Obserwacji takiej dokonać może zarówno klinicysta, jak i pacjent, notując w odpowiednich rubrykach słowa, w trakcie realizacji których występuje niepłynność lub pojawiają się inne symptomy towarzyszące (np. nieprawidłowy sposób oddychania, napięcie mięśniowe, obecność współruchów).

W istocie narzędzie to w żaden sposób nie mierzy niepłynności mówienia. Pomaga jedynie zebrać materiał wyrazowy - tytułową kontrolną listę reakcji - do jakościowej analizy niepłynności mówienia i symptomów jej towarzyszących. Co więcej, kwestią dyskusyjną wydaje się wcielanie się pacjenta w rolę oceniającego. Jak potwierdza praktyka kliniczna w obszarze diagnozowania osób z zaburzeniami płynności mówienia, rejestracja i opis objawów niepłynności czy symptomów towarzyszących leży w gestii logopedy. Prawidłowo zarejestrowana wiedza deskryptywna daje podstawy do rzetelnej interpretacji. Ta z kolei prowadzi do diagnozy wstępnej, podlegającej weryfikacji na podstawie specjalistycznej wiedzy i zdobytych informacji o pacjencie. Ponadto repertuar wypowiedzi - na podstawie których dokonywana jest ocena jakościowa poszczególnych objawów - jest zbyt ubogi. Nie uwzględnia chociażby zachowań narracyjnych, które należy przeciwstawić zachowaniom dialogowym.

Tymczasem Diagram jąkania według P. Lukinga (Balbutiogram nach Luking) [37,38] stanowi graficzną reprezentację danych zebranych w trakcie badania logopedycznego, dotyczących stopnia i charakteru niepłynności mówienia. Uwzględnia dwa przedziały wiekowe: dzieci w wieku 7-9 lat oraz dzieci starsze i dorośli. Zawiera znacznie bardziej zróżnicowany repertuar tekstów: ciągi zautomatyzowane, powtarzanie, czytanie, mówienie spontaniczne. Każda próba opatrzona jest uszczegółowionym systemem poleceń. W przypadku oceny realizacji ciągów zautomatyzowanych pacjent proszony jest o wyliczenie dni tygodnia, nazw miesięcy, pór roku; liczenie do 10 i wspak, recytację wiersza. Realizacja czynności powtarzania zakłada powtórzenie przez badanego sześciu zdań składających się z 12-15 sylab (dzieci w wieku 7-9 lat) bądź dłuższych (dzieci starsze i dorośli). Podobnie w przypadku próby dotyczącej czytania - pacjent czyta głośno sześć wybranych samodzielnie zdań. W ocenie realizacji wypowiedzi podczas swobodnej rozmowy pod uwagę bierze się sześć pierwszych zdań wypowiedzianych przez osobę jąkającą się. Procedura obliczania wyniku polega na naniesieniu 
„plusów” bądź „minusów” do diagramu (za każdą udaną próbę pacjent otrzymuje „plus”, za próbę nieudaną - „minus"). Pozytywna ocena próby ma miejsce tylko wówczas, gdy badany całkowicie płynnie, np. policzy do 10, powtórzy, przeczyta czy wypowie dane zdanie. Prócz oceny płynności wypowiedzi diagram przewiduje również ocenę tzw. symptomów krańcowych, obejmujących: artykulację (np. bełkot, „kluski w gębie”), oddychanie (np. mówienie na wdechu, płytki oddech), dyspozycję werbalną (np. przyspieszone tempo mówienia, arytmia), współruchy (np. mrużenie oczu, napięcie warg), obciążenia psychiczne (np. lęk związany z mówieniem, fizyczne objawy stresu). Badający uzyskane wyniki („plusy” i „minusy”) odnotowuje $\mathrm{w}$ odpowiednich rubrykach diagramu.

Niewątpliwą zaletą omawianego narzędzia jest czytelna forma zestawienia wyników badania w postaci diagramu. Rozwiązanie takie stanowi cenną pomoc diagnostyczną dla terapeuty dokonującego okresowej oceny postępów terapii. Zarejestrowane dane mogą okazać się przydatne przede wszystkim $\mathrm{w}$ procedurze weryfikacji hipotez diagnostycznych i oceny skuteczności wybranej metody postępowania terapeutycznego. Na pewno Diagram... nie sprawdzi się w ocenie ilościowej symptomów niepłynności mówienia, zmierzającej ku diagnozie zaburzeń płynności mówienia. Nawet gdyby przyjąć formułę liczenia "minusów" (prób nieudanych) w stosunku do "plusów" (prób udanych), to rozbieżności między faktyczną liczbą niepłynnie wypowiedzianych wyrazów/sylab a tą odnotowaną w diagramie mogą być bardzo duże. Dla finalnego wyniku badania nie ma bowiem znaczenia, czy w zdaniu składającym się z 15 sylab symptomy niepłynności mówienia wystąpią $\mathrm{w}$ jednej sylabie czy też w piętnastu sylabach. Zadaniem badającego jest - niezależnie od liczby niepłynnie zrealizowanych sylab - umieszczenie we właściwej rubryce formularza „minusa” jako sygnału świadczącego o niepłynności.

Pośród narzędzi diagnostycznych opisanych w piśmiennictwie światowym sporą popularnością cieszą się skale. W przypadku zaburzeń płynności mówienia są one stosowane w ocenie ilościowej niepłynności mówienia, do określania stopnia tej patologii oraz w identyfikacji i opisie symptomów towarzyszących niepłynności.

I tak Iowa skala ciężkości jąkania (ang. Iowa scale rating severity of stuttering) [36] stawia sobie za cel zobiektywizowany opis całościowego zachowania językowego osoby jąkającej się. Parametry oceny ciężkości jąkania zawarto w przedziale „0-7”, gdzie „0” oznacza brak jąkania, zaś „7” - jąkanie najbardziej zaawansowane. Wśród zmiennych, na podstawie których następuje opis stopnia zaburzenia, odnajdujemy: odsetek słów zrealizowanych niepłynnie, zakres napięcia nerwowego, czas trwania przerw w czasie mówienia, dźwięki wtrącone, grymasy twarzy, współruchy.

Z kolei Skala ciężkości jąkania (ang. Stuttering severity scale) R. L. Lanyona [39] skonstruowana została z sześćdziesięciu czterech stwierdzeń, odnoszących się do zróżnicowanych aspektów jąkania, uszeregowanych zgodnie $\mathrm{z}$ rangą ich ważności. Zadaniem jąkającego się pacjenta jest ustosunkowanie się do poszczególnych tez poprzez ich aprobatę bądź dezaprobatę (np. 1. „Gdy rozmawiam, często brak mi powietrza”;
16. Unikam pewnych miejsc, ponieważ obawiam się, że mógłbym się jąkać”; 54. „Często, gdy rozmawiam, mam wzrok utkwiony w ziemi”). Im wyższa akceptacja zamieszczonych twierdzeń, tym cięższy stopień jąkania.

Warto zaznaczyć, że o ile pierwsza z zaprezentowanych skal może być użyta do ilościowej oceny niepłynności na podstawie tak zwanej "próby wyrazowej” (stosunek liczby niepłynnie wypowiedzianych wyrazów do ogólnej liczby wypowiedzianych wyrazów), o tyle skala opracowana przez Lanyona nie mierzy niepłynności mówienia, a jedynie sprawdza dokonaną subiektywnie przez badanego ocenę prawdziwości poszczególnych twierdzeń, odnoszących się do roli zaburzenia w życiu pacjenta.

Ciekawą propozycją do oceny niepłynności mówienia i objawów jej towarzyszących wydaje się Stuttering severity instrument for children and adults (SSI-4) $\left(4^{\text {th }}\right.$-ed.) w opracowaniu Glyndona D. Rileya [40]. To najnowsza, standaryzowana czwarta wersja Skali ciężkości jąkania dla dzieci i dorosłych (ang. Stuttering severity instrument for children and adults) [41]. Narzędzie zostało znormalizowane na grupie 72 dzieci w wieku przedszkolnym, 139 dzieci w wieku szkolnym i 60 osobach dorosłych. Służy do oceny i monitorowania niepłynności mówienia u dzieci w wieku przedszkolnym i szkolnym oraz u dorosłych w czterech aspektach: 1) częstotliwość, 2) czas, 3) fizyczne cechy towarzyszące, 4) naturalność mówienia. Pomiar ilościowy niepłynności mówienia odbywa się na podstawie „próby sylabowej” (procent liczby niepłynnie wypowiedzianych sylab w stosunku do ogólnej liczby wypowiedzianych sylab). Przy czym minimalna długość próbki wypowiedzi wynosi 150 sylab (maksymalnie do 500 sylab). W przypadku dzieci niepotrafiących czytać ocenie podlega realizacja wypowiedzi mówionej, natomiast u pozostałych osób - realizacja wypowiedzi mówionej i podczas czytania. Zmienną czasu stanowi uśredniony czas trwania trzech najdłuższych niepłynnych realizacji zaokrąglony do 0,1 sekundy. Fizyczne cechy towarzyszące niepłynności uszeregowano w czterech kategoriach: dźwięki rozpraszające (sapanie, świsty, wciąganie nosem, dmuchanie, mlaskanie/cmokanie); grymasy twarzy (drganie szczęki, wystający język, zaciskanie warg, napięte mięśnie szczęki); ruchy głowy (do tyłu, do przodu, odwracanie się, utrata kontaktu wzrokowego, stałe rozglądanie się dookoła); ruchy całego ciała (ruch ręki i ramienia, ręce przy twarzy, ruch tułowia, ruchy nóg, stukanie stopą lub kołysanie stopy). Ocena współruchów jest dokonywana na podstawie skali „0-5”, gdzie „0” oznacza brak jakichkolwiek symptomów towarzyszących, zaś „,5” - ich poważną i dotkliwą widoczność. Z kolei wskaźniki „naturalności mówienia" zamieszczono w przedziale 1-9. Im wyższa nota, tym większy stopień „nienaturalności”. Procedura wyliczania wyniku badania sprowadza się do przeliczenia poszczególnych danych, tj. odsetka sylab wypowiedzianych niepłynnie, średniego czasu trzech najdłuższych niepłynnych realizacji oraz nasilenia fizycznych współruchów, na punkty, których suma daje wynik ogólny. Uzyskaną punktację porównuje się ze skalą określającą stopień ciężkości jąkania (bardzo łagodne, łagodne, umiarkowane, poważne, bardzo poważne), dostosowaną do wieku pacjenta.

Istnieje również możliwość automatycznej kalkulacji częstotliwości i czasu trwania niepłynności przy użyciu 
specjalnego oprogramowania komputerowego (CSSS 2.0), dołączonego do narzędzia. Badający lewym klawiszem myszy odznacza wszystkie sylaby wypowiedziane przez pacjenta, prawym - zrealizowane niepłynnie, z kolei - poprzez przytrzymanie klawisza - czas trwania niepłynności. Wyniki pomiaru niepłynności mówienia przy użyciu tego rodzaju techniki nie zostały dotychczas opublikowane. Jednak - jak podkreślają badacze - wiarygodność wspomnianej procedury w dużej mierze zależy od dostatecznego wytrenowania umiejętności obsługi programu [42].

Całościowa ocena czwartej edycji skali w opracowaniu Rileya wypada zadowalająco. Zastosowanie "próby sylabowej” w ocenie ilościowej niepłynności mówienia w precyzyjny sposób pozwala na ustalenie jej stopnia nasilenia. Co istotne, SSI-4 umożliwia również ocenę symptomów towarzyszących, które - $\mathrm{w}$ procedurze diagnozy różnicowej - poddawane są konfrontacji z innymi, podobnymi objawami, występującymi w poszczególnych jednostkach patologii mowy. Warto byłoby jednak rozszerzyć korpus badań cząstkowych, na podstawie których dokonywana jest ocena płynności mówienia, uwzględniając zarówno wypowiedzi dialogowe, jak i narracyjne.

\section{Wyniki}

Opis i analiza metod oceny płynności mówienia musi uwzględniać: przyjęcie określonej definicji płynności i niepłynności mówienia, określenie kryteriów rozróżniających płynność mówienia od niepłynności (fizjologicznej i patologicznej) oraz zagadnienie różnicowania typów niepłynności patologicznej w przypadkach poszczególnych zaburzeń.

Kwestią niezwykle istotną jest rozróżnienie terminów: niepłynność mówienia i jąkanie. Jak dowodzi praktyka kliniczna, utożsamianie obu pojęć jest mylne i prowadzi do fałszywych wyników w procedurze oceny płynności wypowiedzi. Ponadto, z perspektywy refleksji naukowej, płynność mówienia nie jest zjawiskiem z gruntu normatywnym, opartym wyłącznie na naturalnej obserwacji oceniającego. Całkowita płynność mówienia występuje epizodycznie.

Zgodnie z przyjętymi definicjami, kluczowymi kategoriami kwalifikacji niepłynności mówienia jako fizjologicznej i patologicznej są symptomy niepłynności i stopień ich nasilenia. W odniesieniu do kryterium objawowego, niepłynność mówienia podlega analizie jakościowej i ilościowej. Ocena jakościowa obejmuje fonetyczne objawy niepłynności oraz symptomy towarzyszące niepłynności patologicznej; zaś oceny ilościowej dokonuje się zazwyczaj na podstawie „próby wyrazowej” bądź „próby sylabowej”. Granicą patologii jest 5\% całkowitej niepłynności ocenianej w próbie sylabowej. W praktyce klinicznej obie zmienne (ilość i jakość) są równie istotne.

Niepłynność patologiczna jest objawem występującym $\mathrm{w}$ różnych jednostkach nozologicznych jako rezultat patologii procesów związanych z czynnością mowy. W diagnozie różnicowej poszczególnych zaburzeń należy zatem wziąć pod uwagę: specyfikę niepłynności mówienia, dodatkowe symptomy jej towarzyszące, pełną dokumentację diagnozowanej osoby oraz dane uzyskane w trakcie wywiadu.
Funkcjonujące w logopedii metody oceny płynności mówienia ukierunkowane są zarówno na ocenę ilościową (częstotliwość niepłynności mierzona w próbie wyrazowej bądź sylabowej), jak i ocenę jakościową (typ niepłynności oraz występowanie symptomów towarzyszących) niepłynności. Powszechnie stosowaną techniką oceny jest procedura „off-line” (na podstawie nagrania wypowiedzi pacjenta). Formularz badania uwzględnia na ogół: wiek pacjenta oraz zróżnicowane typy zadań (zachowań werbalnych). Wymóg standaryzacji badania nakazuje wykorzystanie do oceny niepłynności mówienia różnego rodzaju narzędzi diagnostycznych: testów, kwestionariuszy, prób, list, diagramów czy skal. W logopedycznej praktyce międzynarodowej są to również techniki skomputeryzowane. Dla uzyskania obiektywnej i skutecznej oceny płynności wypowiedzi ważny jest nie tylko dobór odpowiedniego narzędzia, lecz także sama technika przeprowadzania pomiaru.

Przegląd narzędzi do oceny płynności mówienia funkcjonujących w piśmiennictwie krajowym i międzynarodowym pozwala na sformułowanie następujących wyników: 1. Kwestionariusz Niepłynności Mówienia i Logofobii Tarkowskiego, Test Fluencji Słownej, Kontrolna lista reakcji w jąkaniu, Skala ciężkości jąkania Lanyona nie oceniają płynności mówienia wedle przyjętej definicji. Co prawda ewentualna ocena materiału uzyskanego $\mathrm{z}$ ich zastosowaniem może mieć wartość o charakterze eksperymentalno-klinicznym, jednak podobny walor ma również ocena innych wypowiedzi pacjenta. Mało tego, zarówno w kwestionariuszu Tarkowskiego, jak i w skali Lanyona o patologii niepłynności mówienia decyduje subiektywna ocena pacjenta. Co ciekawe, Test Fluencji Słownej to narzędzie ugruntowane przede wszystkim $\mathrm{w}$ diagnostyce neuropsychologicznej w psychiatrii i neurologii [43]. Płynność słowna jest tu więc mylnie utożsamiana z płynnością mówienia. W przypadku Kontrolnej listy reakcji w jąkaniu Johnsona, Darleya i Spriestersbacha miernikiem patologii niepłynności wypowiedzi jest wyłącznie naturalna obserwacja (pacjenta lub badającego), pozbawiona oceny ilościowej.

2. W ocenie płynności mówienia (ilości i jakości objawów) zasadne wydaje się wykorzystanie następujących narzędzi: Kwestionariusza Cooperów Oceny Jąkania (KCOJ) w adaptacji Chęćka („próba wyrazowa”), Iowa skali ciężkości jąkania („próba wyrazowa”) oraz Skali ciężkości jąkania dla dzieci i dorostych (SSI-4) w opracowaniu Rileya, wzbogaconej o specjalistyczne oprogramowanie komputerowe do zautomatyzowanego pomiaru częstotliwości i czasu trwania niepłynności („próba sylabowa”). Należy jednak podkreślić, że wyłącznie w przypadku Próby sylabowej... Kurkowskiego mamy do czynienia z pomiarem niepłynności jako wyizolowanego objawu, występującego niezależnie od danej jednostki nozologicznej.

3. W świetle opisu i analizy metod oceny płynności wypowiedzi należy zaznaczyć, iż model klinicznej oceny płynności mówienia winien bazować nade wszystko na naukowej refleksji logopedycznej. Jej osią konstrukcyjną w tym przypadku jest przyjęcie odpowiedniej definicji płynności i niepłynności mówienia oraz obiektywnych kryteriów rozróżniania płynności mówienia od niepłynności: fizjologicznej i patologicznej. Kwalifikacji wypowiedzi jako niepłynnej - zwłaszcza niepłynnej patologicznie - dokonujemy bowiem na podstawie 
objawów artykulacyjnych przywołanych w definicji. Wszelkiego rodzaju zabiegi upotocznienia terminologii z obszaru zaburzeń płynności mówienia w rezultacie prowadzą do błędnych wyników w procesie diagnostyczno-terapeutycznym.

\section{Podsumowanie}

Obiektywna i skuteczna klinicznie metoda oceny płynności mówienia musi brać pod uwagę: ocenę ilościową (częstotliwość niepłynności) i jakościową niepłynności (opis objawów z uwzględnieniem reakcji i zachowań im towarzyszących) oraz technikę pomiaru od strony formalnej. Należy pamiętać o specyfice każdego z zaburzeń, w którym występują objawy niepłynności, oraz o konieczności oglądu zaobserwowanych symptomów w szerszej perspektywie, w której istotne znaczenie mają także dane uzyskane w trakcie wywiadu klinicznego oraz analiza dokumentacji pacjenta.

Wydaje się, że optymalnym rozwiązaniem byłoby narzędzie łączące precyzyjny pomiar ilościowy (ocena częstotliwości i czasu trwania niepłynności mierzona w próbie sylabowej) z rzetelnym pomiarem jakościowym (ocena rodzaju niepłynności i symptomów jej towarzyszących na podstawie kwestionariusza) wspartym techniką obiektywizującą ten pomiar od strony formalnej. W związku $\mathrm{z}$ tym rekomendujemy częściowo zautomatyzowany pomiar w próbie sylabowej, zakładający automatyczną detekcję przeciągnięć, powtórzeń, dźwięków wtrąconych, obliczanie czasu pauz (próba sylabowa przy użyciu specjalnego oprogramowania komputerowego) w połączeniu $\mathrm{z}$ fachową oceną ekspercką czynności i objawów zaobserwowanych w trakcie badania (specjalistyczny kwestionariusz obserwacji klinicznej).

Procedura oceny polegałaby na automatycznym zaznaczaniu sylab zrealizowanych niepłynnie, czasu trwania niepłynności (w tym czasu trwania pauz) za pomocą technik skomputeryzowanych oraz na wskazaniu przez eksperta na podstawie obserwacji zachowań językowych pacjenta
- symptomów towarzyszących niepłynności. Zaletą takiego rozwiązania jest przede wszystkim możliwość szybkiego zorientowania się w wartości ilościowej niepłynności mówienia u pacjenta. Jeśli chodzi o samą technikę pomiaru od strony formalnej, właściwą strategią wydaje się ocena dokonywana na podstawie nagrania wypowiedzi pacjenta, czyli w trybie „off-line”. Niejednokrotnie wyłącznie praktyka odsłuchiwania nagrań sesji diagnostycznej gwarantuje obiektywną ocenę symptomów towarzyszących niepłynności, a tym samym prawidłowe rozpoznanie przypadku. Dodatkowo powinno się dokonać oceny tempa wypowiedzi (abstrahując od pauz).

Próby, w ramach których byłby dokonywany pomiar niepłynności, powinny uwzględniać zróżnicowany typ zachowania werbalnego: powtarzanie, czytanie, opowiadanie, dialog neutralny/emocjonalny. Trudno natomiast w warunkach badania klinicznego obiektywne ocenić zmienne różnych rozmówców i sytuacji.

Osobną i ważną kwestią pozostaje wypełnienie i uwzględnienie w końcowej ocenie specjalistycznego kwestionariusza obserwacji klinicznej, dotyczącego symptomów towarzyszących wypowiedzi: napięcia mięśniowego, sposobu oddychania, jakości głosu, artykulacji, gramatyczności i spójności wypowiedzi. Konieczne do oceny w tym wypadku są odpowiednie kompetencje eksperta dokonującego obserwacji.

Analiza precyzyjnych danych dotyczących liczby i rodzaju występujących niepłynności, czasu ich trwania, tempa mówienia, czasu trwania pauz oraz objawów towarzyszących pozwoli na całościową i rzetelną ocenę płynności mówienia.

Artykut powstat $w$ zwiazku $z$ realizacja projektu „Zintegrowany system narzędzi do diagnostyki i telerehabilitacji schorzeń narzqdów zmysłów (słuchu, wzroku, mowy, równowagi, smaku, powonienia)" wspólfinansowanego przez Narodowe Centrum Badań i Rozwoju w ramach Programu STRATEGMED.

\section{Piśmiennictwo:}

1. Shriberg E. Phonetic Consequences of Speech Disfluency. Citeseerx.ist.psu.edu; 1999.

2. Yaruss JS. Clinical Measurement of Stuttering Behaviors. www. asha.org/uploadedFiles/asha/publications/cicsd; 1997.

3. Einarsdóttir J, Ingham RJ. Have disfluency-type measures contributed to the understanding and treatment of developmental stuttering? Am J Speech Lang Pathol, 2005; 14(4): 260-73.

4. Woźniak T. Niepłynność mówienia. W: Grabias S, Kurkowski M, red. Logopedia. Teoria zaburzeń mowy. Lublin: Wydawnictwo UMCS; 2013, s. 549-64.

5. (Von) Essen O. Fonetyka ogólna i stosowana. Warszawa: PWN; 1967.

6. Engiel Z. Próba opracowania systemu ćwiczeń logopedycznych w rehabilitacji jąkania. Cz I. Zagadnienia wychowawcze a zdrowie psychiczne, 1976; 6: 60-63.

7. Engiel Z. Próba opracowania systemu ćwiczeń logopedycznych w rehabilitacji jąkania. Cz. II-IV. Zagadnienia wychowawcze a zdrowie psychiczne, 1977; 1,2,3: 79-83, 81-84, 70-71.
8. Woźniak T. Pojęcie jąkania a metodyka postępowania logopedycznego. W: Opuscula logopaedica. Lublin: Wydawnictwo UMCS; 1993, s. 313-19.

9. Szeląg E. Nowe metody terapii wyzwaniem XXI wieku. Logopedia, 1999; 26, 215-24.

10. Wierzchowska B. Fonetyka i fonologia języka polskiego. Wrocław: Ossolineum; 1980.

11. Guitar B. Stittering: An integrated approach to its nature and treatment. Baltimore-Philadelphia: Wolters Kluwer Health, $4^{\text {th }}$ Edition; 2014.

12. Tarkowski Z. Jąkanie. Warszawa: PWN; 1999.

13. Tarkowski Z. Jąkanie wczesnodziecięce. Warszawa: WSiP; 1992.

14. Kurkowski ZM. Próba sylabowa do oceny niepłynności mówienia. Warszawa: Stowarzyszenie Przyjaciół Osób Niesłyszących i Niedosłyszących „Człowiek-Człowiekowi”, wyd. 2. poprawione i uzupełnione; 2007.

15. Grabias S. Postępowanie logopedyczne. Diagnoza, programowanie terapii, terapia. Logopedia, 2008; 37: 13-27.

16. Sidor M. Niepłynność mowy w jąkaniu. Lublin: Wydawnictwo UMCS; 2011. 
17. Woźniak T. Standard postępowania logopedycznego w przypadku jąkania. Logopedia, 2008; 37: 217-26.

18. Woźniak T. Standard postępowania logopedycznego w przypadku giełkotu. Logopedia, 2008; 37: s. 227-34.

19. Lewandowski A, Tarkowski Z. Dyzartria. Wybrane problemy etiologii, diagnozy i terapii. Warszawa: Wydawnictwo ZSL; 1989.

20. Łuria AR. Zaburzenia wyższych czynności korowych wskutek ogniskowych uszkodzeń mózgu. Wprowadzenie do neuropsychologii. Warszawa: Państwowe Wydawnictwo Naukowe; 1967.

21. Jastrzębowska G. Podstawy teorii i diagnozy logopedycznej. Opole: Uniwersytet Opolski; 1998.

22. Sobów T, Sławek J. Zaburzenia poznawcze i psychiczne w chorobie Parkinsona i innych zespołach parkinsowskich. Wrocław: Continuo; 2006

23. Kozanecka E. Zaburzenia komunikacji związane z zaburzeniami psychicznymi. W: Gałkowski T, Jastrzębowska G, red. Logopedia - pytania i odpowiedzi. Podręcznik akademicki. Opole; 2003, s. 286-90.

24. Maniecka-Aleksandrowicz B, Domeracka-Kołodziej A. Wybrane zagadnienia z patologii głosu. W: Gałkowski T, Szeląg E, Jastrzębowska G, red. Podstawy neurologopedii. Podręcznik akademicki. Opole; 2005, s. 475-516.

25. Jastrzębowska G, Pelc-Pękała O. Diagnoza i terapia mowy upośledzonych umysłowo. W: Gałkowski T, Jastrzębowska G, red. Logopedia. Pytania i odpowiedzi. Opole; 1999, s. 775-87.

26. Mielnik-Błaszczak M, Michałowski A. Zespół Gilles de la Touretta - opis przypadku. Nowa Stomatologia, 2005; 3: 130-31.

27. Kurkowski ZM, Trochymiuk A, Muzyka E. Standard postępowania logopedycznego w przypadku zaburzeń słuchu. Logopedia, 2008; 37: 29-37.

28. Jani L, Huckvale M, Howell P. Procedures used for assessment of stuttering frequency and stuttering duration. Clin Linguist Phon, 2013; 27(12): 853-61.

29. Codello I, Kuniszyk-Jóźkowiak W. Wave Blaster - a comprehensive tool for speech analysis and its application for vowel recognition using wavelet continuous transform with bark scales. 56 Otwarte Seminarium z Akustyki OSA, 2009, s. 63-68.
30. Codello I, Kuniszyk-Jóźkowiak W, Smołka E, Kobus A. Automatic prolongation recognition in disordered speech using CWT and Kohonen network. Journal of Medical Informatics \& Technologies, 2012.

31. Codello I, Kuniszyk-Jóźkowiak W, Smołka E, Kobus A. Automatic disordered sound repetition recognition in continuous speech using CWT and Kohonen network. Annales UMCS Informatica, 2012.

32. Codello I, Kuniszyk-Jóźkowiak W, Smołka E, Kobus A. Automatic disordered syllables repetition recognition in continuous speech using CWT and correlation. Advances in Intelligent and Soft Computing, 2013.

33. Ponichtera-Kasprzykowska M, Sobów T. Adaptacja i wykorzystanie testu fluencji słownej na świecie. Psychiatria i Psychologia Kliniczna, 2014; 14(3): 178-87.

34. Tarkowski Z. Kwestionariusz Niepłynności Mówienia i Logofobii (diagnoza i terapia jąkania). Lublin: Wydawnictwo Polskiej Fundacji Zaburzeń Mowy; 1992.

35. Chęciek M. Kwestionariusz Cooperów do Oceny Jąkania. Lublin: Fundacja Zaburzeń Mowy; 1992.

36. Johnson W, Darley W, Spriestersbach D. Diagnostic methods in speech pathology. New York: Haper and Row Publishers; 1963.

37. Böhme C. Das Stotter - Synndrom. Stuttgart: Hipokrates-Verlag; 1977.

38. Tarkowski Z. Zagadnienie etiologii, diagnozy, terapii i prognozy. Warszawa: Wydawnictwo ZSL; 1987.

39. Lanyon RL. The measurement of stuttering severity. Journal of Speech and Hearing Research, 1967; 10: 838-43.

40. Riley GD. Stuttering severity instrument for children and adults (SSI-4) ( $4^{\text {th }}$-ed.). Austin, TX: Pro Ed; 2009.

41. Riley GD. A stuttering severity instrument for children and adults. Journal of Speech and Hearing Disorders, 1972; 45: 314-22.

42. Bakker K. Computerized Scoring of Stuttering Severity (CSSS2.0). Austin, TX: Pro Ed; 2009.

43. Piskunowicz A, Bieliński M, Zgliński A, Borkowska A. Testy fluencji słownej - zastosowanie w diagnostyce neuropsychologicznej. Psychiatria Polska, 2013; XLVII (3): 475-85. 